\title{
APE 2015 Sponsors and Supporters
}

\author{
Main Sponsors (3 days): \\ Elsevier \\ Springer Science+Business Media \\ Full Sponsors (2 days): \\ IOS Press \\ Hindawi Publishing Corporation \\ Co-Sponsors:
}

Akademische Verlagsgesellschaft AKA

Aries Systems

Atypon

EBSCO Information Services

De Gruyter

MDPI - Open Access Publishing

International Association of Scientific, Technical \& Medical Publishers

John Wiley \& Sons, Wiley-VCH

Offering discounts to their members:

ALPSP - Association of Learned and Professional Society Publishers

Arbeitskreis Elektronisches Publizieren/AKEP

German Association of Publishers and Booksellers (Börsenverein des Deutschen Buchhandels)

DGI - German Society for Information (Deutsche Gesellschaft für Information)

Gesellschaft für Informatik (GI)

International Council for Scientific and Technical Information (ICSTI)

International Association of Scientific, Technical \& Medical Publishers 